of gallstones with an ursodeoxscholic acid-menthol preparation a controlled prospective double hlind trial. Gut 1988:92:+28 -32.

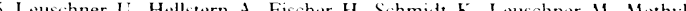
tert-hutyl ether for gallstone dissolution, clinical results and toxicity.

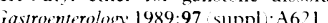

6 Kellett MJ, Wickham JEA, Russell RCG. Percutancous cholecystolithotom BrMed Y 1988:296:453-5.

7 Wickham JEA. Miller RA. Percutaneous renal surgery. London: Churchill Livingstone, 1983

8 Villanova $\mathrm{N}$, Bazzoli $\mathrm{F}$, Taroni $\mathrm{F}$, et al. (Gallstone recurrence after successful oral bile acid treatment. A 12 vear follow up study and evaluation of long term post dissolution treatment. Gasiroenterolugy 1989;97:726-31.
9 Pers $\mathrm{M}$, Baden $\mathrm{H}$. On the frequency of recurrence of calculi in the gallbladder fter cholecrstolithotomy tow Chir Siand 1952;102:260-6.

10 Norrby S, Schoncbeck J. Long term results with cholecrstolithotomy tcta Chir Scand 1970;136:711-3.

11 Anonymous. (jallstones, bile acids and the liver [Editorial]. Lance 1989;ii: $249-51$

12 Spengler V, Sackman M, Sauerbruch T, Holl J, Paumgartner G. Gallbladder motility before and after extracorporeal shockwave lithotripsy: Gastroenterologe 1989;96:860-3.

Accepted 22 February 1990

\title{
Comparison of vascular tone during combined haemodialysis with ultrafiltration and during ultrafiltration followed by haemodialysis: a possible mechanism for dialysis hypotension
}

\section{John R Bradley, David B Evans, Alan J Cowley}

\section{Department of Renal \\ Medicine, Addenbrooke's Hospital, Cambridge CB2 2QQ \\ John R Bradley, MRCP, senior registrar \\ David B Evans, FRCP \\ consultant physician}

Department of Medicine, University Hospital,

\section{Nottingham}

Alan J Cowley, DM, senior lecturer

Correspondence to: Dr Bradley.

Br Med f 1990;300:1312-3
Haemodialysis is frequently complicated by severe and symptomatic hypotension, which is associated with and may be caused by abnormalities of peripheral venous tone.' Hypotension during haemodialysis can, however, be prevented if ultrafiltration is performed separately from dialysis. ${ }^{2}$ If inappropriate changes in peripheral vascular tone are important in the development of dialysis induced hypotension we would expect them not to occur during isolated ultrafiltration. We therefore compared changes in peripheral vascular tone and blood pressure during combined ultrafiltration and haemodialysis with those during sequential ultrafiltration and haemodialysis.

\section{Patients, methods, and results}

Four men and four women (mean age 52 (SD 16)) undergoing long term haemodialysis gave their informed consent, and the local ethical committee approved the study. Patients first received combined acetate haemodialysis and ultrafiltration for four hours, during which fluid was removed at a continuous rate. One week later patients underwent isolated ultrafiltration for one hour followed by acetate dialysis without removal of fluid for four hours. During ultrafiltration the same amount of fluid as had been lost the previous week was removed.

Forearm blood flow and venous tone were measured every 15 minutes during dialysis by venous occlusion plethysmography using mercury in Silastic strain gauges in the arm without the fistula. Venous tone was measured as the increase in volume of the forearm when a venous occlusion cuff was inflated to $40 \mathrm{~mm} \mathrm{Hg}$ around the upper arm causing the venous bed to fill. An increase in the index of venous tone indicated venodilatation. Forearm vascular resistance was calcu-

Mean (SE) rates of change in haemodynamic variables during combined dialysis and ultrafiltration and during ultrafiltration followed by dialysis

\begin{tabular}{|c|c|c|c|}
\hline & \multirow{2}{*}{$\begin{array}{l}\text { Combined haemodialysis } \\
\text { and ultrafiltration }\end{array}$} & \multicolumn{2}{|c|}{$\begin{array}{l}\text { Sequential ultrafiltration and } \\
\text { dialysis }\end{array}$} \\
\hline & & Lltrafiltration & Dialysis \\
\hline Heart rate $($ beats $/ \mathrm{min} / \mathrm{h}$ ) & $2 \cdot 3\left(0 \cdot 43^{\star \star}\right.$ & $0 \cdot 2 \quad 1 \cdot 16$ & $2.4(0.68)$ \\
\hline Mean arterial pressure $(\mathrm{mm} \mathrm{Hg} / \mathrm{h})$ & $-5 \cdot 2(1 \cdot 13 \star \star \star$ & $7 \cdot 6 \quad 2 \cdot 28)$ & $1.7(0.44)$ \\
\hline Forearm venous tone $(\mathrm{ml} / 100 \mathrm{ml}$ over $40 \mathrm{~mm} \mathrm{Hg} / \mathrm{h})$ & $0 \cdot 27(0 \cdot 05)^{\star \star}$ & $0.45(0.09)^{\star}$ & $0 \cdot 33(0 \cdot 06)^{\star \star}$ \\
\hline Forearm vascular resistance (arbitrary units/h) & $1.8(0.51)^{\star}$ & $15 \cdot 8(4.33)^{\star}$ & $5.2(1.73)^{\star \star}$ \\
\hline
\end{tabular}

${ }^{\star} \mathrm{p}<0 \cdot 05 ;{ }^{\star \star} \mathrm{p}<0 \cdot 01$, signed ranks test. lated by dividing mean arterial pressure by forearm blood flow, which was measured by standard techniques. ${ }^{+}$Changes in plasma volume were calculated from changes in the packed cell volume.

To determine the significance of changes in haemodynamic variables the slopes of regression lines of each variable with time during each procedure were calculated for each patient by the least squares method Whether regression slopes differed from zero was tested using the signed rank sum test.

During combined haemodialysis and ultrafiltration for four hours plasma volume fell by 14.5 (SE 1.7)\%. Forearm vascular resistance increased but the forearm venous bed dilated inappropriately and mean arterial blood pressure fell (table). During isolated ultrafiltration for one hour plasma volume fell by $18 \cdot 6(2 \cdot 2) \%$. Forearm vascular resistance increased considerably, the forearm venous bed constricted appropriately, and mean arterial pressure did not change significantly. During subsequent dialysis for four hours plasma volume returned to $90.9(1.9) \%$ of the preultrafiltration level. During this refilling of the vascular bed forearm vascular resistance fell and the forearm venous bed dilated but mean arterial pressure remained stable.

\section{Comment}

One of the main aims of haemodialysis is to remove excess fluid. This is initially achieved by reducing plasma volume, and the integrity of peripheral vascular responses is essential if blood pressure is not to fall. The results of this study suggest that dialysis induced hypotension may be associated with abnormalities of both the arteriolar and venous sides of the circulation. During combined dialysis and ultrafiltration there was a considerable fall in blood pressure associated with only a small increase in forearm vascular resistance and inappropriate dilatation of the venous bed.

These abnormalities of peripheral vascular tone did not occur during isolated ultrafiltration, when the forearm veins constricted and forearm vascular resistance almost doubled. These changes in vascular tone, which are appropriate responses to a reduced plasma volume, may account for the well recognised cardiovascular stability during isolated ultrafiltration."

In the absence of any difference in plasma volume depletion between ultrafiltration alone and in combination with dialysis the different peripheral vascular responses are presumably due to the effects of dialysis. Correction of the metabolic derangements of renal failure probably withdraws a stimulus to vasoconstriction.

1 Bradlev JR, Evans DB, Gore SM. Cowley AJ. Is dialysis hypotension caused by an abnormality of venous tone? Br.Med 7 1988;296: 1634-7.

2 Bergstrom J, Asaba H, Furst P, Oules R. Dialysis, ultrafiltration, and bloos pressure. Proc Liar Dial Transplant dssoc 1976;13:293-305.

Bevegard BS, Shepherd JT. Changes in the tone of limb veins during supine exercise. 7 Appl Physiol 1965:20:1-8.

Greenfield ADII, Whimer. RJ, Mowbray Jl: Methods for the investigation of peripheral bleod flow. Br. Med Bull 1963:19:101-9.

Beuph W ments. F Appl Physiol 1972:32:712-3. 